\title{
Veterinary use of thermal water and mud from Lake Hévíz for equestrian injury prevention and rehabilitation
}

\author{
Bartos, A. ${ }^{1}$, Bányai, A. ${ }^{1}$, Koltay, I. ${ }^{1}$, Ujj, Zs. ${ }^{1}$, Such, N. ${ }^{1}$, Mándó, Zs. ${ }^{2}$, Novinszky P. ${ }^{3}$ \\ ${ }^{1}$ Georgikon Faculty, University of Pannonia, 8360 Keszthely, Hungary; ${ }^{2}$ Saint Andrew Hospital for Rheumatic Diseases, \\ Hévíz, Hungary; ${ }^{3}$ University of Veterinary Medicine, Budapest, Hungary
}

Corresponding author: Ádám Bartos, Ph.D. tel.: +36-30-9739-295 bartos-a@ georgikon.hu _

\begin{abstract}
The beneficial effects of thermal water and mud treatment in the human medical field have been investigated and well known for many years. However, such treatment has never been studied and used in veterinary science. The aim of our study was to investigate how a mud treatment from Héviz Spa Lake affects the movement quality and flexibility of certain joints in horses. This medical mud, which is unique on the world, contain about 70-80 \% thermal water from the Lake. Wet sludge was applied on the knee, hock, elbow, shoulder, back, stifle, front and hind cannons and fetlock joints for a period of eight weeks. Our results show, that the mud treatment from Héviz Spa Lake may have beneficial effects on the joints, playing important role in the locomotion of horses. The positive results of this experiment and the benefit of the water from the Lake in human field give us the idea to plan a balneotherapeutic equine medical centre next to the outlet canal of the Heviz Spa Lake. The main component of this centre is a covered balneotherapeutic equine walker. In this centre we could make complex hydro- and balneotherapeutic treatments for horses and we could use the medical mud as a supplemental treatment. This equine centre would be absolutely unique on the world.
\end{abstract}

Keywords - thermal mud, Lake Héviz, veterinary use, horse movement quality, flexibility of joints, balneotherapeutic centre

\section{Lake Héviz - a geological curiosity}

Lake Héviz is Europe's largest thermal lake - a warm water lake situated in a peat-bed. The 4.44 ha water-surface lake (Figure 1) is surrounded by a 60.5 ha nature conservation area. ${ }^{1}$

Springs of different temperatures mix in a narrow cave and became a constant $\left(38,5{ }^{\circ} \mathrm{C}\right)$ temperature stream when entering the lake. Beautiful water lilies, brought to Hungary at the end of the 19th century, dot the lake, supporting the ecolife, with leaves slowing down evaporation, and creepers protecting the medicinal mud on the bottom of the lake. Hévíz

\footnotetext{
${ }^{1}$ A preliminary account of this work has been presented at the conference "Developmental potentials in terms of nutrition, exercise and health" held in Rakican, Slovenia on October 25-26, 2016.
}

Thermal Lake and traditional human treatments are from the year 2015 part of National Heritage. The thermal water comes from an about $40 \mathrm{~m}$ deep situated cave (Bergmann, 2014).

\section{Effect of medical mud on the joints and locomotion activities of horses}

Medical research for humans provided evidence regarding the beneficial effects of thermal mud in the treatment of rheumatism (Gyarmati and Kulisch 2008).

As a result, the thermal sludge product has been developed, which is successfully applied more widely, especially in the 
rehabilitation of rheumatic diseases (Gyarmati et.al., 2012). Research results related to the management of horses for the time being, however, are not available.

The aim of our study was to investigate how a mud treatment from Héviz Spa Lake affects the movement quality and flexibility of certain joints in horses. The average stride length and the longest distance between the print of hind and front foot during walking and trotting are very important marks in the movement quality by horses. The higher results are better (Németh et al., 2007). The higher flexibility of certain joints affects better movement activity and higher elasticity.

\section{Materials and methods}

Hévíz medical mud is a mixture of turf next to Hévíz and water from the thermal lake, which was produced in a modern mud factory. This is an organic mud with dark grey color and soft texture. Main components: thermal water (72-82 \%), minerals (4.5-7.7\%), organic material (13.5-14.3\%), sulphur (2.4\%), humic acids (5\%) (Bartos et al., 2015).

An experiment was carried out with 10 male and female school and sport horses. All of the horses had been ridden longer period than 3 years and had a correct and healthy movement. Horses were treated with mud ten times, respectively, twice daily in the evenings.

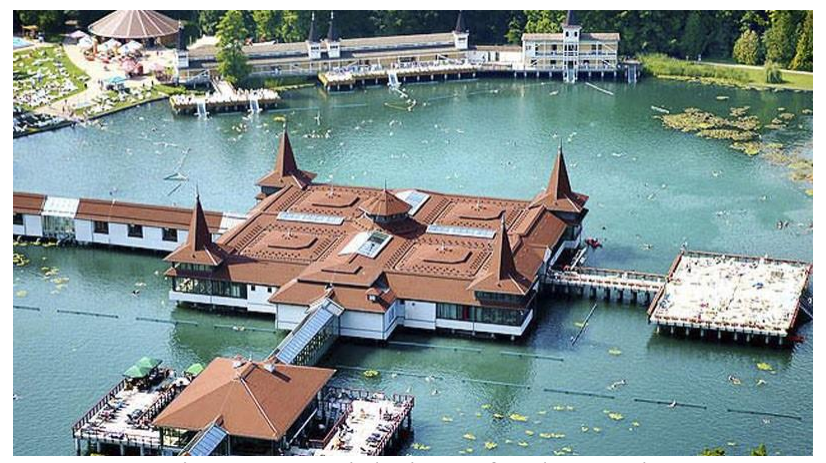

Figure 1. Aerial view of Lake Héviz

Source: https://en.wikipedia.org/wiki/Lake Hévíz

Wet sludge was applied on the knee, hock, elbow, shoulder, back, stifle, front and hind cannons and fetlock joints (Figure 2).

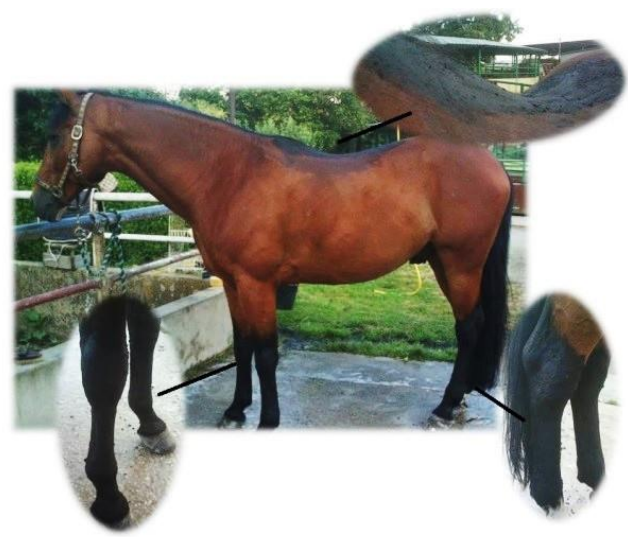

Figure 2. Treated parts of the body.
The sludge used for treatments was washed off in the morning. Before the experiment, at the end of the mud treatments and 8 weeks following the average stride length and the longest distance between the print of hind and front foot during walking and trotting (Figure 3), maximal flexibility of knee, hock and fetlock joints were measured. To calculate the number of steps horses were led straight during walking and trotting on a $30 \mathrm{~m}$ long flat surface. Following this the stride length was determined. To determine the longest distance between the print of hind and front foot on flat, sandy soil, the distance between hind and front prints was measured three times. The maximal flexibility of each joint was measured with a joint protractor (Figure 4). Statistical analysis was carried out with one-way analysis of variance (ANOVA) with SPSS 7.0 program.

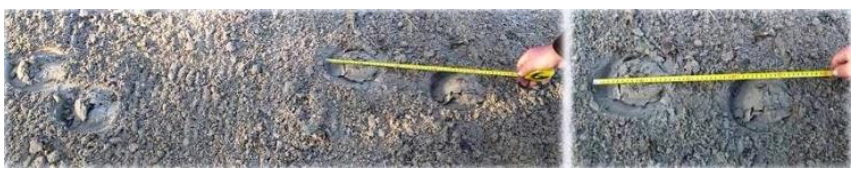

Figure 3: The measurement of the longest distance between the print of hind and front foot
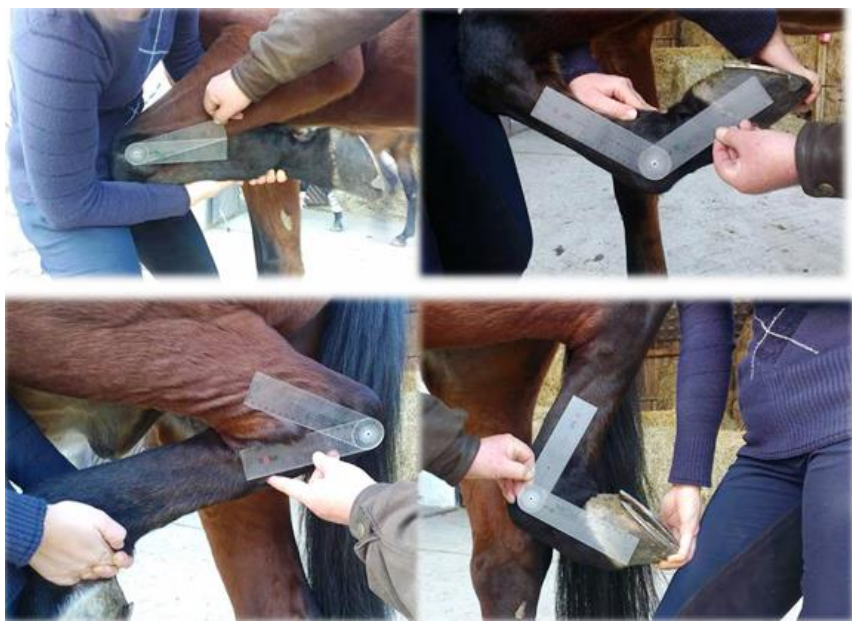

Figure 4. Measurment of flexibility.

\section{Results and discussion}

According to the results (Table 1), the horses responded positively to the treatments. In case of horses movement quality is a very important parameter. The most positive results were detected directly after the treatments by the average stride length during walking, maximal flexibility of the front and hind fetlock and knee, in the case of hock we observed only a positive tendency. This is partly explicable with the beneficial effects of sulphur on the joints, which is well-known in human field (Kovács et.al. 2012). The stride length (during trotting) and longest distance between the print of hind and front foot were slightly but positively influenced by the mud treatment. Eight weeks after the treatments, most of the parameters similar to human therapeutic results (Kulisch et.al. 2012), compared to directly after the mud baths completion values were further improved, a slight negative effect was observed only for a few test values, but the results obtained here were more favourable, as at the beginning of the experiment. The results seem to confirm that the treatment 
Table 1. Effects of Hévíz thermal mud treatments on the examined parameters.

\begin{tabular}{|c|c|c|c|}
\hline & Before treatment & $\begin{array}{c}\text { After } \\
\text { treatment }\end{array}$ & $\begin{array}{c}8 \text { Weeks after } \\
\text { treatment }\end{array}$ \\
\hline Average stride length during walking (m) & $1,80 \pm 0,07 \mathbf{a}^{*}$ & $1,86 \pm 0,12 \mathbf{a b}$ & $1,93 \pm 0,11 \mathbf{b}$ \\
\hline Average stride length during trotting (m) & $2,45 \pm 0,22 \mathbf{a}$ & $2,63 \pm 0,24 \mathbf{a}$ & $2,67 \pm 0,20 \mathbf{a}$ \\
\hline $\begin{array}{l}\text { Longest distance between the print of hind and front } \\
\text { foot during walking }(\mathrm{cm})\end{array}$ & $30,80 \pm 10,17 \mathbf{a}$ & $31,25 \pm 10,26 \mathbf{a}$ & $33,06 \pm 12,85 \mathbf{a}$ \\
\hline $\begin{array}{l}\text { Longest distance between the print of hind and front } \\
\text { foot during trotting }(\mathrm{cm})\end{array}$ & $17,65 \pm 9,04 \mathbf{a}$ & $22,80 \pm 10,10 \mathbf{a}$ & $19,13 \pm 12,94 \mathbf{a}$ \\
\hline Maximum flexibility of knee (Deg.) & $39,5 \pm 2,8 \mathbf{a}$ & $36,2 \pm 3,5 \mathbf{a b}$ & $33,8 \pm 5,3 \mathbf{b}$ \\
\hline Maximum flexibility of hock(Deg.) & $49,2 \pm 6,21$ & $47,8 \pm 9,45$ & $46,6 \pm 8,35$ \\
\hline Maximal flexibility of front fetlock joint (Deg.) & $121,5 \pm 7,47 \mathbf{a}$ & $112,7 \pm 9,41 \mathbf{b}$ & $115,6 \pm 2,39 \mathbf{a b}$ \\
\hline Maximum flexibility of hind fetlock joint (Deg.) & $92,0 \pm 9,49 \mathbf{a}$ & $83,6 \pm 6,72 \mathbf{a b}$ & $81,9 \pm 6,51 \mathbf{b}$ \\
\hline
\end{tabular}

* Averages with different letters in a row differ significantly $(\mathrm{p}<0,05)$

effects can be considered long term. This is also explained by the slurry preparation from which absorbed elemental sulphur and sulphur oxidizing hydrogen sulphide absorbed in the body may be another source of hydrogen sulphide formation at the skin (Gyarmati 1982). Our results show, that the mud treatment from Heviz Spa Lake may have beneficial effects on the joints, playing important role in the locomotion of horses.

Our results show, that the mud treatment from Hévíz Spa Lake may have beneficial effects on the joints, playing research has to be carried out to confirm the results. The results of the present experiment and the prospect of further research could be pioneer, as the Héviz mud, as well as the thermal effect of water even before in the equine medicine has not been demonstrated experimentally, only individual observations are available. Thus, the veterinary use of Héviz mud, which has been proven many times in human medicine, seems to be a new research field.

The results are remarkable as well, also because of the evidence of the chemical impact of mud also can help. Such modes of action are still under research and only partly demonstrated in human medicine (Odabasi et.al. 2008). Further veterinarian research has to be carried out to confirm the results. The results of the present experiment and the prospect of further research could be pioneering, as the Héviz mud, as well as the thermal effect of water even before in the equine medicine, have not been demonstrated experimentally, only individual observations are available. So the veterinary use of Héviz mud, which has been proven many times in human medicine, seems to be a new research field.

The concept of a Balneotherapeutic equine medical center
Medical research for humans provided evidence regarding the beneficial effects of thermal water in prevention and rehabilitation (Bender 2008, Borszéki 1998, Peralta 2004). In the case of Heviz water, important positive effects were observed also by hand and knee osteoarthtosis (Kovács et al., 2012, Kulisch et al., 2014). Human results in the case of the locomotion system can be adapted for horses (Young, 2007.) The benefits in human field and our positive results with medical mud (which contain 70-80 \% thermal water) give us the idea to plan a balneotherapeutic equine medical centre.

The centre would be situated near the lake, next to the outlet canal. Today horses can't be treated directly in the lake because of the modern infrastructure. Interestingly, about 100 years ago an elephant from the Budapest Zoo was treated against rheumatism in Lake Heviz (Figure 5). The water quality and temperature in the outlet canal are similar to those of the water in the Lake (Tóth et al., 2015).

Main components of the planned centre (Figure 6) are:

- Balneotherapeutic horse walker for four horses

- Stable with 4 boxes and 2 treating boxes with equine solarium

- Pump house

- Reed root water cleaning system

- Solar panels - photovoltaic energy.

The covered balneotherapeutic walker (Figure 7) is the main element of the centre. The most important function of the walker is medical treatment and rehabilitation. The water level in the equipment can be regulated with pumps, so this can also be useful for training various muscle groups (Seawalker, 2013). (Figure 8)

Treating boxes in the stable with equine solarium (Figure 9) are for drying horses after the water treatment. This solarium is also good for warming the muscles of the horses and can decrease the lactic acid production in the muscles (Pongrácz, 
2007). In these boxes, we can make also supplementary mud treatments with medical mud.

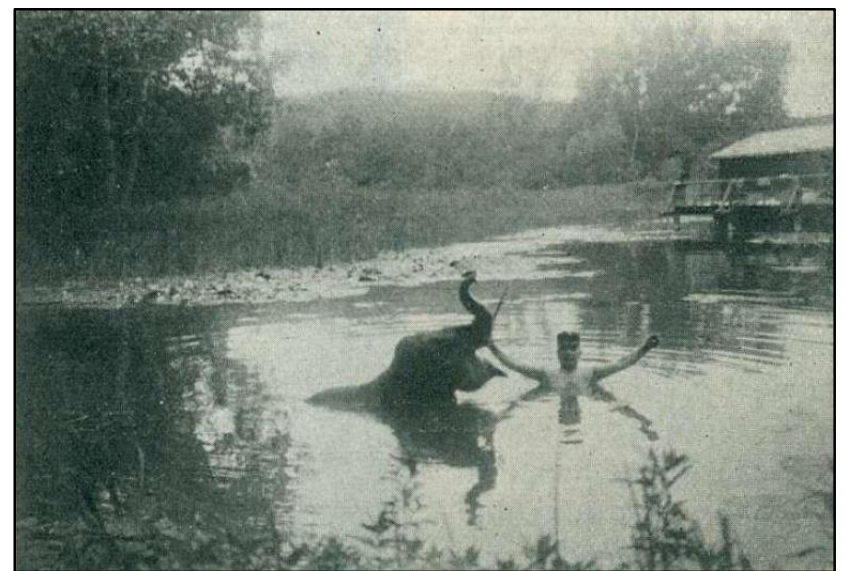

Figure 5. Nelly the elephant in Lake Héviz in 1914. Source: https://zoobudapest.com/ezt-latnod-kell/hirek/nelly-elefant-

\section{hevizi-kezelese}

In the wall of 4 stable boxes, there are salt bricks (Figure 10), which function as salt cells, which can be a supplementary treatment for the respiratory system of the horse.

For the energy supply of the centre, we would like to use a solar cell system (photovoltaic energy), which is environmentally friendly and economical. For removing horse faeces from the water, a special reed bed system (Figure 11), a natural wastewater purification system based on root filtration, microbial activity and physical aeration of the soils (Némethy and Molnár, 2013) shall be installed.

Reed beds are able to tackle ammonia, heavy metals, suspended solids, sewage, organic petrochemical derivatives including diesel and various solvents, phenol and phenolic compounds, pesticides and faecal coliforms, bacterial contamination, etc. This system can decrease the nitrogen and phosphorus content of the water and the eutrophication can be decreased or prevented in the outlet canal (Simándi, 2011).

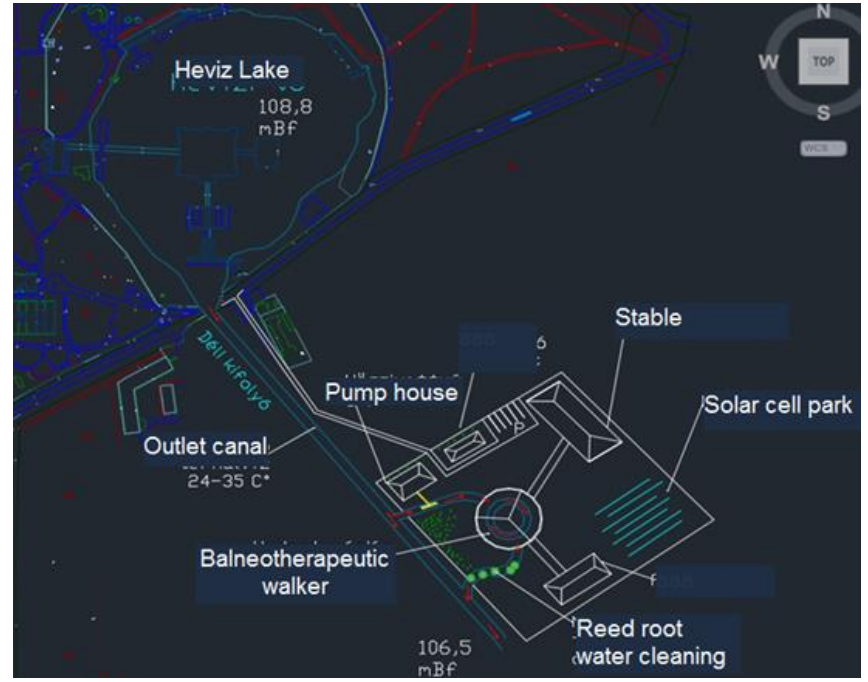

Figure 6. Layout plan of the balneotherapeutic centre.

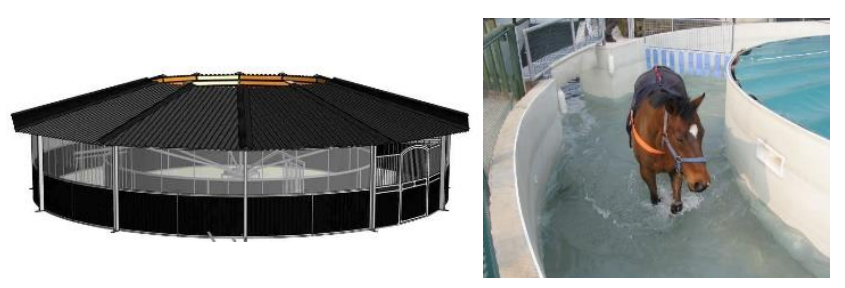

Figure 7. Layout of the covered horse-walker.

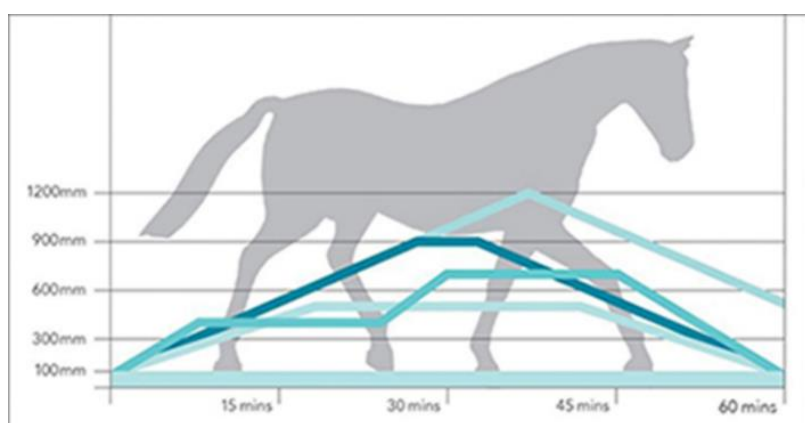

Figure 8. Hydrotherapeutic muscle treatment with different water level.

www.equinehealthcentre.com/seawalker/products
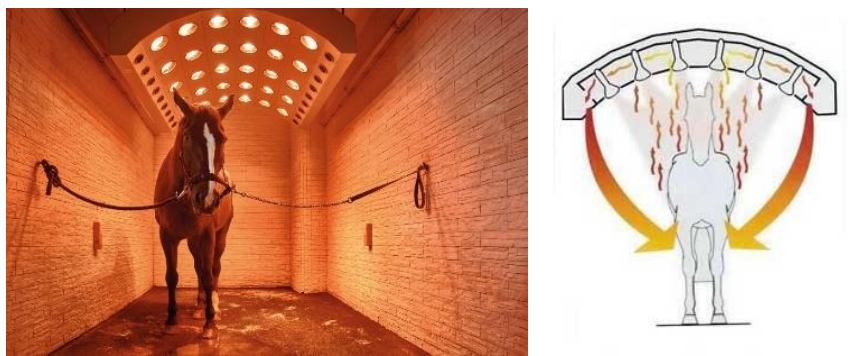

Figure 9. Equine solarium with air circulation for drying the ventral part of the horse.

\section{Conclusions}

The equine medical centre would have an important role in horse health, in prevention and rehabilitation, with the water level regulation it is also good for muscle and condition training of horses. This centre can be used as a research centre. The results of equine experiments are also very useful in human balneotherapeutic research because there is no placebo effect in horses. The system is very environmentfriendly, economical and can be used without stress for horses. The centre can be used all year round because the temperature of water in the canal is never below $22{ }^{\circ} \mathrm{C}$. Very important, that this balneotherapeutic centre would be absolutely unique in the world.

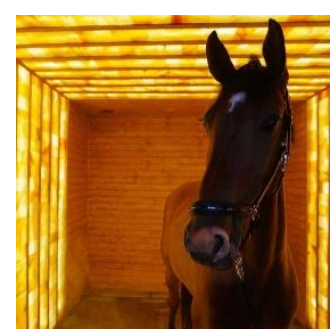

Figure 10. Salt bricks in the wall of a box. 


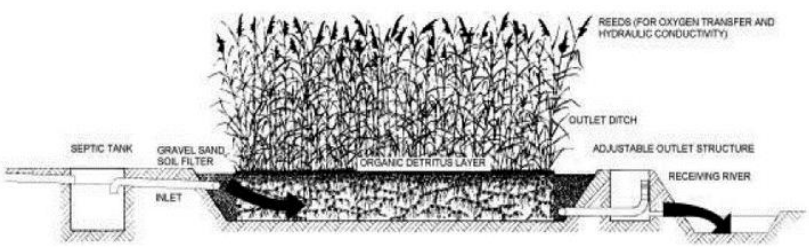

Figure 11. Reed bed water cleaning system. http://adlib.everysite.co.uk/adlib/defra/content.aspx?id $=000$ HK277ZW.0AAW9925TJA42BE

\section{Acknowledgements}

The work was supported by the EFOP-3.6.3-VEKOP-162017-00008 project. The project was co-financed by the European Union and the European Social Fund.

\section{References}

Bartos A., Bányai A., Koltay I., Mándó Zs. (2015): Effect of mud treatment from Hévíz Spa Lake on the joints and locomotion activities of horses. Proceedings of $3 \mathrm{rd}$ International Equine Science Meeting. Nürtingen, 28-29. May (ISBN 978-3-95625-000-2)

Bender T. (2008): Medicinal bathing and other physioterapeutic treatments. (In Hungarian), SpringMed Kiadó Kft.

Bergmann A. (2014): Therapies in Héviz. Spring Med, Budapest

Borszéki B. Gy.(1998): Mineralwater, medicinal water. (in Hungarian), MÉTE Kiadó

Gyarmati, J. (1982): Experiences of Heviz mud treatments. FITEC Congress, Budapest

Gyarmati, N. and Kulisch Á. (2008): History and description of héviz spa with special emphasis on weight-bath. La Presse thermale et climatique 2008; 145:233-242.

Gyarmati N., Mándó, Zs., Bergmann, A., Mózes, M. (2012.): The role of mud treatment in the rehabilitation of reumatic illnesses. XXXI: Conference of The Hungarian Society for Medical Rehabilitation and Physical Medicine 6-8. September. Szombathely, Hungary

Kovács C., Pecze M., Tihanyi Á., Kovács L., Balogh S., Bender T. (2012): The effect of sulphurous water in patients with osteoarthritis of hand. Double-blind, randomized, controlled follow-up study. Clinical Rheumatology 31(10): 1437-42. DOI: $10.1007 / \mathrm{s} 10067-012-2026-0$

Kulisch, Á. and her medical team (2012): Survey of Heviz thermal-mineralwater on patienten suffering from primer knee-arthrosis. As medicinal declaration of human research. Essay, Saint Andrew Hospital for Reumatic Diseases, Heviz, Hungary

Kulisch, Á. and her medical team (2014): Evaluation of the effect of Lake Hévíz thermal mineral water in patients with osteoarthritis of the knee: a randomized, controlled, singleblind, follow-up study. Eur $J$ Phys Rehabil Med. Aug;50(4):373-81. Epub. 2014 Mar.

Németh Cs., Pataki B., Antal I. (2007): Codex of equine performanc. (in Hungarian) Mezögazdasági Szakigazgatási Hivatal Központ

Némethy S. and Molnár G. (2013): Key issues of lake management in connection with mitigation of adverse effects of climate change, agriculture, sustainable regional development, energy production and development of sustainable tourism. Zeszyty Naukowe WSTiE, Sucha Beskidzka, Poland. ISSN: 2084-8722, 4/2013, pp. 24-54

Odabasi, E., Turan, M., Erdem, H., Tekbas, F. (2008): Does mud pack treatment have any chemical effect? A randomized controlled clinical study. Journal of Alternative \& Complementary Medicine; Jun, Vol. 14 Issue 5, p559 DOI: $\underline{10.1089 / \mathrm{acm} .2008 .0003}$

Peralta M. A. (2004): Medical water of Hungary. (in Hungarian) CARITA Bt.

Pongrácz L. (2007): Horsepower (in Hungarian) Equinter, Budapest

Seawalker (2013): Revolutionary new cross training waterwalker from Seawalker takes performance training to a new level. www.equinehealthcentre.com/seawalker/products

Simándi, P. (2011): Wastewater clenaning technologies II. (in Hungarian), Digitális Tankönyvtár www.tankonyvtar.hu

Tóth, Gy. (2015): Hévíz Lake 2009-2015: Research, monitoring-development, practical water management. XXII. Conference on under earth waters, 8-9 April, Siófok.

Young, G. (2007): Healing Horses. What works for us, works for them. Horse Connection Magazine VII. (7.) 